Tér és Társadalom 17. évf. 2003/1. 1-17. p.

\title{
A REGIONÁLIS TUDOMÁNY DUALITÁSA ÉS PARADIGMÁI - HAZAI TÜKÖRBEN
}

\author{
(Duality and Paradigm of Regional Science - \\ in the Hungarian Mirror) \\ NEMES NAGY JÓZSEF
}

Kulcsszavak:

regionális tudomány társadalomelmélet térelmélet paradigma

A tanulmány - egy általános deduktiv modellen és a regionális kutatások jelenlegi magyar föaramának értékelésén alapulva - a regionális udomány elméleti struktúráját és tartalmát vizsgálja. A regionális tudomány mint tärsadalomtudomány a terïleti folyamatokhoz kapesolócló különbözó regionális kutatások alapvetö fogalmait, elméleteit és módszereit integrálja. Fö elméleti keretét az általános társadalomelméletek és a társadalmi térelmélet dualitása adja. A regionális kutatások által vizsgált folyamatok két fö sajátos iránnyal rendelkeznek: a valós társadalmi folyamatok elemzése, illetve a közigazgatás rendszereinek kutatása. Ezek a folyamatok szorosan kapcsolódnak a regionális elentzés és tervezés céljaihoz és módszereihez. A szerzö a regionális tudomány négy paradigmájára mutat rá: a társadalmi tér és a területi struktúrák elemeire, mint a diszciplina két általános paradigmája, és a települések és a régiók paradigmáira, mint a külsö földrajzi tér speciális paradigmái.

A regionális tudomány tartalmára, céljaira vonatkozó meghatározásokat keresve, sokfajta meghatározásra bukkanhat a kutató. Kár lenne azonban ezt valamifajta sajátos, önmarcangoló negatívumként, komoly kritikai érvként értelmeznünk, hisz nincs ez másként a többi tudományág esetében sem. Még a legtradicionálisabb diszciplínák esetében is természetesen befolyásolja a kutatási súlypontokat, a célok és eszközök, az intézményrendszer tartalmát a folytonos változás, a tudományos fejlődés.

Enyedi György újabb írásaiban, előadásaiban (legutóbb Enyedi 2002a) azt, a nemzetközi tudományosságban is fellelhető álláspontot képviseli, ami a mai regionális tudományt transzdiszciplináris tudáskészletként határozza meg, amellyel a területileg mindig egyenlötlen társadalmi fejlődés vizsgálata végezhető (a transzdiszciplinaritást - idézi Timár J. [2001] - a társadalomföldrajz is magáénak vallja). Magam sok tekintetben szimpatizálok ezzel a tudomány-elméleti szempontból elegáns, az intézményesültség szempontjából pedig realista meghatározással, noha az ez idáig kiizzadt definícióm bizonyos tekintetben szükebb szemléletet tükröz: „A regionális tudomány a társadalmi tértudományok legalapvetöbb közös fogalmait, elméleteit, módszereit egységes rendszerbe foglaló és a társadalmi jelenségeket és folyamatokat ezek felhasználásával vizsgáló társadalomtudomány" - írtam a Tér a társadalomkutatásban c. könyvemben (Nemes Nagy 1998, 19).

A hazai szakirodalomban mindkét szemlélethez közeli vélemények megjelentek már. Többen, föként a tudományközi viszonyokat a szükséges empátiával szemlélö geográfusok (pl. Mészáros 2000) Enyedi szemléletével rokonszenveznek, az inkább az önálló diszciplináris jelleg felé hajlók közül Horváth $G y$. (2001) lényegében az 
én definíciómat vette át, amikor értékelte a hazai regionális kutatásokat. Sokan vannak, akik csak egyszerủen dolgoznak, és nem izgatja őket a diszciplináris karakter kérdése, bár minden komoly kutató, ha nem is morfondírozgat tudománydefiníciókon (ami teljesen normális személyiségjegy), müveivel maga is állást foglal a legáltalánosabb szemléleti kérdésekben is.

Ez az írás nem valamifajta, csekély haszonnal járó definíció-vita újraélesztésének kísérlete, s nem utólagos - s így értelmetlen - reflexió a közelmúltban hazai akadémiai berkekben lezajlott diszciplínavitához. (Ugyanakkor nagyon egyetértek Berényi I. (2002) megállapításával - aki ugyan nem a regionális tudományról ír, de kifejezetten ilyen típusú kérdéseket feszeget, amikor a kultúrföldrajzban látja megvalósíthatónak a geográfiai szintézist -, miszerint nem szerencsés, hogy a tudomány-elméleti és rendszertani problémák ,elhallgatottak”.) A szokványos rövid meghatározások keresése helyett inkább a regionális kutatások főbb csomópontjainak, elágazásainak feltérképezésével próbálkozom.

\begin{abstract}
Az ilyen vagy olyan definíciótól függetlenül, a hazai regionális tudomány történetére és mai státuszára pillantva megállapítható, hogy az egyre halmozódó tudásanyag, a felértékelődött gyakorlati hasznosulás, a szervezeti gazdagodás ellenére valódi diszciplináris elismerése, a tudomány-rendszertani és szervezeti hierarchiákba való stabil beillesztése még várat magára. Ez azzal együtt is tény, hogy a kilencvenes években, miközben mértékadó nemzetközi publikációkban a regionális tudomány válságáról olvashattunk, itthon példátlanul megerösödött e kutatási irány (Enyedi 2002b). A hazai regionális tudomány ezzel együtt ténylegesen inkább csak az elegáns „transzdiszciplináris tudáskészlet” státuszáig ért el (ezt távolról sem tartom lekicsinyelhető fejlódési szintnek, de a tudáskészlet mégsem diszciplína) - ezért is használtam a fentiekben Enyedi meghatározására a realista jelzőt. Hozzá teszem: a ma érvényes hazai tudományos taxonómiában a regionális tudománynak a multidiszciplináris társadalomtudomány kategóriájában jut hely.
\end{abstract}

A következőkben a transzdiszciplinaritás és a társadalmi tértudományi jelleg építőkockáit, elméleti és koncepcionális elemeit boncolgatom, kitekintve a nemzetközi tapasztalatokra is, de döntően a hazai kutatási irányokra figyelve. Az elméleti keretek és paradigmák áttekintése, valamifajta rendszerbe szedése éppúgy lehet az egyre többek által mủvelt regionális kutatások irányzatai közötti eligazodás, mint az egység megtalálásának lehetséges eszköze. A tudományközi kapcsolódások is világosabbá válhatnak így, ami a diszciplínák közötti kevés hasznú rivalizálásnak is jó ellenszere lehet. A tanulmányon végigvonul a regionális tudomány karakterének, tartalmának határozott megfogalmazására való törekvés, ami kétségkívưl el is határolja a diszciplínát a többi tudományterülettől. Ebben az a vélelmem is tükrözödik, hogy a tudományközi kooperáció - amit létszükségletnek tartok - sokkal hatékonyabb világos célú és eszközrendszerú tudományterületek között, mint a kusza átfedettség viszonyai mentén.

A tudományág fogalmi építőkockáit egy, szándékaim szerint szép szimmetriával esztétizált, deduktív modellre füztem (1. ábra). A modell négy fogalomkörböl építkezve jellemzi a regionális tudományt. E négy fö dimenziót az elméleti keretek, a vizsgált folyamatok, a vizsgálati célok és - legbelül - a regionális kutatások mögött (vagy elött) mindenkor kimutatható, egyidejűleg is létező, s így gyakran konkuráló 
Nemes Nagy József : A regionális tudomány dualitása és paradigmái - hazai tükörben.

Tér és Társadalom 17. évf. 2003/1. 1-17. p.

tudományos szemléletek, koncepciók, paradigmák alkotják. Ezek egymásban és egymás mellett való elhelyezkedése és a modellen meg nem jeleníthető, de a késöbbiekben fontos szempontként visszatérỏen említett időbeli hullámzásuk, történetiségük adja azt a sajátos elméleti-szemléleti konfigurációt, ami a regionális tudományi kutatások kereteit és jellegzetes irányait jelöli ki.

\section{1. ÁBRA}

A regionális tudomány elméleti keretei és paradigmái

(Theoretical Frames and Paradigm of Regional Science)

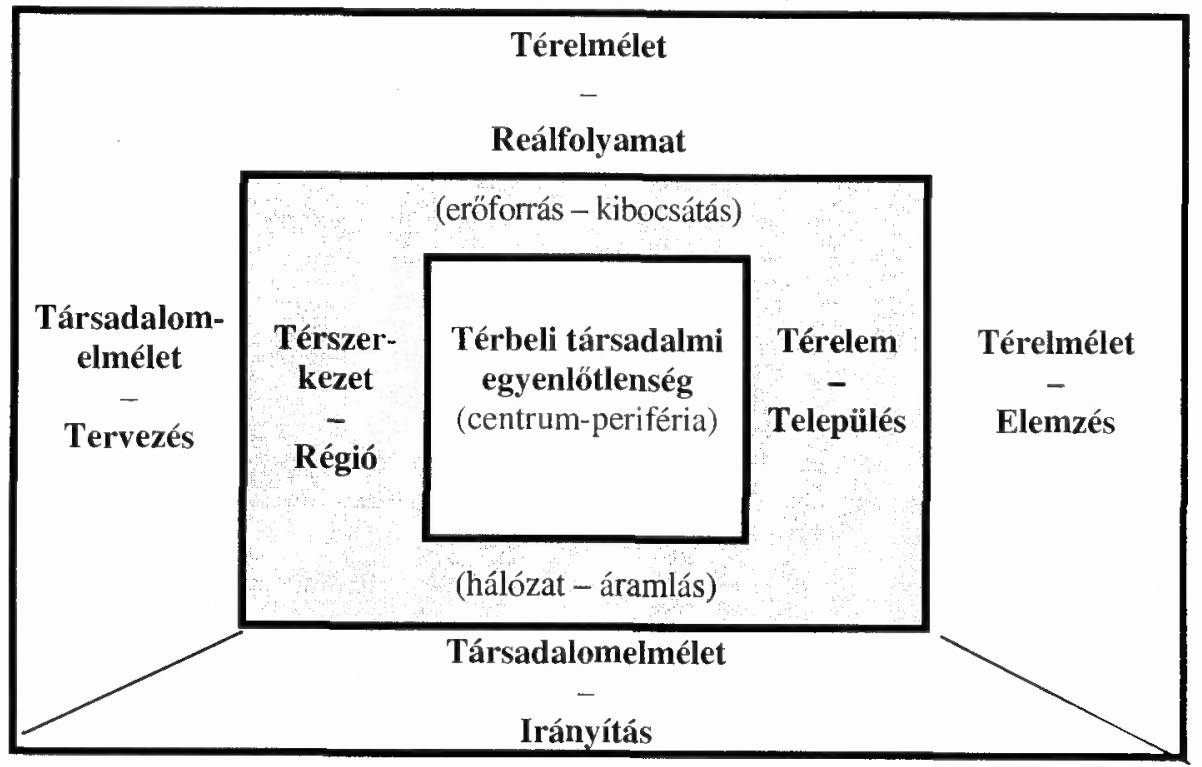

Forrás: Saját szerkesztés.

\section{Elméleti keretek: társadalomelmélet-térelmélet}

A modell alapkoncepciója, kerete a regionális tudomány elméleti dualitása, együttes társadalomelméleti illetve térelméleti tartalma.

Ez a szemlélet azt jelenti, hogy a társadalomelmélet mellett a felhasznált diszciplínakészletnek (a „transzdiszciplínának”) minden vizsgált tudományos kérdést átható, alapvetỏ elemének tekintem a térelméletet is. Nélküle beszélhetünk ugyan területi kérdések vizsgálatáról, mint a társadalomelemzés egyfajta sajátos megfigyelési egységekből kiinduló közelítéséről, de csak a regionális tudományon kíviul. Ezek a közelítések leginkább az egyes társadalmi tértudományokban vagy a területpolitika gyakorlati területeihez kapcsolódóan helyezhetők el. A legtöbb tér-ökonometriai modell vagy a területi tervdokumentumok jellemzó példák minderre. Kissé szubjektivizálva, tartalmazza továbbá ez a kettősség azt is, hogy minden regionalistának illendó a maga szemléletét és felkészültségét elhelyezni e duálban, s mindazoknak, akik a szélső pólusok közelében lévőnek találtatnak - tiszta „,társada- 
lomtudós” vagy igazi „térkutató” - indokolt a közép felé indulnia. (Attól persze, hogy a helyén marad, még megmaradhat kiváló tudósnak, a „regionalistaság” ehhez nem feltétel.)

A regionális tudomány legsajátabb szemléleti momentuma marad ki a gondolkodásmódból és a konkrét kutatási folyamatból, ha a teret (térbeliséget, területiséget) puszta elemzési szempontként, keretként értelmezzük. A társadalomelmélet és a térelmélet tartalmainak együttes érvényesítése még akkor is (vagy a feladat „szépsége" okán épp azért) alapkövetelmény a regionális tudományban, ha a különbözö tudományterületek térszemléletében és alapkategóriáiban nagyon markánsak a különbségek. R. Strassoldo (1990) például a tér, a terület, a környezet kategóriákat sorra a matematikához (geometria, topológia), a társadalomtudományhoz, illetve az ökológiához kötve, határozott különbségekre mutat rá konkrétságuk, komplexitásuk, dinamikájuk, analitikus illetve generális jellegük tekintetében. A térelméleti alapok és kutatások viszonylagos gyengesége a hazai regionális kutatások nagy kockázati eleme.

A többi tudományterülettel és a gyakorlattal kapcsolatokat kereső irányokat megfogalmazó nemzetközi tudományosság (újabban: Markusen 2001), ha nem is lezárt, de leszürt és biztos társadalmi térelméleti ismeretrendszer bázisán szorgalmazhatja a nyitást. A mi ismeretrendszerünkben nincs meggyökeresedve Lefebre „társadalom által termelt" tere (Lefebre 1974), vagy Malmberg emberi territorialitás-elmélete (Malmberg 1980), de a kvantitatív elemzök feltárta sajátos és gazdag, $\mathrm{s}$ ma is bövülö térelemzési eszközrendszer sem.

A társadalomelméleti jellemző más tudományágak teremtette hatalmas ismeretrendszerböl merítve érhetö el, s így föként szelekciós és adaptációs készséget feltételez. Ebben a tekintetben a regionális tudomány is „erösen elméletimportáló tudomány", miként azt Benedek J. $(2002,21)$ a földrajzról írja (hozzá teszem: a módszer-import sem csekély). Bár szigorú követelményként állíthatnánk a regionalisták elé a társadalomtudományok (közgazdaságtan, szociológia, igazgatástudomány stb.) teljes elméleti eszköztárának ismeretét, ennek valóságos teljesítése azonban csak keveseknek adatik meg.

Sok egyéb tényezö mellett két faktor, a térelméleti alapok gyengesége és a nagyon szerteágazó társadalomelméleti gyökerek miatt látszik kockázatosnak - a „sokat markol, keveset fog" veszélyét hordozza - valamifajta önálló regionalista-képzés megindítása graduális szakként az egyetemeken. Ugyanakkor túl késöi fázisnak tünik a regionális tudományi ismeretrendszernek csak a doktori iskolákban való felbukkanása. Saját tapasztalataim szerint a legmegfelelöbb képzési idősávnak a felső évfolyamok szakirányai látszanak, ahol - az alapképzési szakasz intézményenként divergáló, de biztos szakmai tartalmára is építve - átadhatók és kialakíthatók a regionális tudományi szemlélet alapjai is.

A különböző társadalomtudományok fő elméletei, szemlélete és módszerei átvételének csatornái adottak: a regionális tudomány létrejötte ugyanis nem jelenti egyben azt, hogy a többi társadalmi tértudományt (l. regionális gazdaságtan, telepuilésszociológia, társadalomföldrajz) felszívta, bekebelezte volna. A társadalomtudományi ismeretek ezért e tudományterületek közvetítésével eljuthatnak a regionális tudomány eszközei közé. Az ezekben létrejövő új eredmények ismerete, analógiák 
Nemes Nagy József : A regionális tudomány dualitása és paradigmái - hazai tükörben.

Tér és Társadalom 17. évf. 2003/1. 1-17. p.

keresése, az alkalmazási tér kiterjesztése járható út a társadalomelmélet új eredményeinek integrálására. Sokat segíthet ebben, hogy a (hazai) regionalisták mindanynyian valamilyen alapvető társadalomtudományi képzettséggel rendelkeznek, s együttesen talán alkalmasak is az említett elméleti alapok ,importjára”.

A társadalmi térelméleti ismeretek ellenben nem kis részben magán a formálódó regionális tudományon belül születtek az elmúlt fél évszázadban, mégpedig olyan tartalommal, hogy itt a tér, a térkategóriák általános (filozófiai, matematikai, fizikai) jelentése és tartalma csak azok sajátos, az egyes társadalmi szférákra jellemző megjelenésével együtt releváns. A társadalmi térelméleti kutatások nem háríthatók át semmilyen más tudományágra, ebben magáé a regionális tudományé a fö felelösség.

A térelméleti megalapozás talán legfontosabb témakörei nem elsösorban a tér általános filozófiai jelentéséhez kötödnek, hanem sokkal inkább a különbözö térkategóriák világos értelmezéséhez (Szabó 2002), a társadalmi folyamatok adekvát területi szintjeinek és egységeinek megtalálásához. A társadalmi térelmélet számára hatalmas tudományos kihívást jelent ma, hogy a térbeliség látható felértékelődése a társadalmi folyamatokban együtt jár a teljesen új tartalmú és jellegü terek megjelenésével (a „virtuális térröl” 1. Jakobi 2002). Sok írás a manapság felértékelödött szubjektív, szellemi, absztrakt tereket el is választja a „valóságos” tértöl. Nem gondolom, hogy a különbség abban állna, hogy az egyik „,valóságos”, a másik meg „nem-valóságos”. Mindkettő nagyon is valóságos, csak másként. Napjaink legújabb folyamatai minöségi változásokat látszanak hozni az egyik legalapvetôbb térkategória, a távolság tartalmának és hatásainak mintegy két évszázada tartó látványos átajakulásában (a közlekedés és a kommunikáció újabb és újabb eszközei létrejöttének százada a 19. és a 20. század).

A jellegadóan a különböző térkategóriák mentén való gondolkodást és kutatást nemcsak a regionális tudomány önállósága, de léte és jövöje szempontjából is kulcskérdésnek tartom. E szemlélet háttérbe szorultsága megállíthatatlanul ahhoz vezethet ugyanis, hogy a regionális tudomány kénytelen lesz visszahúzódni valahova oda, ahonnan elindult: a közgazdaságtan, a szociológia, a politológia vagy a földrajz valamifajta sajátos, szegmentált al-diszciplínájának szerepkörébe.

A térelméleti háttér még a leggyakorlatiasabb tevékenységek bázisaként is megjelölésre, végiggondolásra érdemes. Jól példázza itthon ezt az, hogy a regionális tudománnyal kapesolatos szinte teljes elutasítás, szkepszis után (Illés 1975) a magát ma már regionalistának valló Illés Iván a hazai területfejlesztés történetének megírásakor is értelmezésre érdemesnek tart (Illés 2002, 13) olyan alapvetó térkategóriákat, mint ,a térbeli, földrajzi egymásmellettiség, differenciáltság, távolság és mobilitás, kiterjedés és tagoltság". (Azt, hogy a tudományos minöség nem önmagából a „regionalistaságból” ered, ékesen bizonyítja mindkét citált munka magas színvonala.)

Arra, hogy a társadalmi jelenségek térbeliségének s ez által elemzésüknek, vizsgálatuknak sajátos, önálló törvényei, szabályai vannak, nagy meggyözỏ erővel mutat rá Varga A. (2002) tanulmânya, ami szinte minden ez idáig nagy hévvel és (ami gyakorta vele jár) felszínességgel végzett (kvantitatív) területi gazdaságtani elemzésünk mögé kérdőjeleket hoz a nemzetközi tudományosság eredményeiből (a késés kb. másfél évtizedes, 1. Anselin-Griffith 1988). A gondolati mag a következő: mivel a társadalmi jelenségek és folyamatok térbelisége az esetek túlnyomó többségében’a térbeli közelségböl fakadó egymásrahatással, hasonulással jár (elegánsabban: a társadalmi tér jellegzetesen pozitív autokorreláltságú), sok területi vizsgálatban csorbát szenved a statisztika egyik alapkövetelményének számító független mintavétel szabálya. Ez általá- 
Nemes Nagy József : A regionális tudomány dualitása és paradigmái - hazai tükörben.

Tér és Társadalom 17. évf. 2003/1. 1-17. p.

nosabban azt is jelenti: a térbeliség nem semleges megfigyelési szempont, hanem a társadalmi folyamatokat, összefüggéseket, konfigurációkat közvetlenül befolyásoló tényezö. Ez a kérdéskör jellemzően azok közül való, ami itthon érdemben még ismeretlen, nem kivitatott (talán indulóban van a késés ledolgozása: l. Dusek 2002a).

A regionális tudomány fél évszázados története a társadalomelméleti és térelméleti dualitás állandó meglétéröl, de egyben a két komponens egymás közötti arányainak jellegzetes változásairól tanúskodik. Ez sajátos tudománytörténeti szakaszokat teremt, amelyek szépen nyomon követhetók $G$. Benko (1999) analizisében is. A változó tudományos hangsúlyokban a társadalmi változások lenyomataira is rábukkanhatunk.

Isard regionális tudományában a komplex társadalmi (közgazdasági) tartalom dominál, ahol a tér, a területegység még inkább csak az egymásra hatás kerete. Az alapmúvében (Isard 1956) célba vett általános elmélet (general theory) nem térelméleti, hanem közgazdaságtani (mai szemléletében is leginkább erre mutat érzékenysége [Isard 1999]). De, már a kezdeteknél felsejlik az a vonulat - amit leginkább a hatvanas (nálunk a hetvenes, nyolcvanas) évek kvantitatív forradalma teljesít ki -, amely a többváltozós matematikai-statisztikai módszereknek és a különbözó térparamétereknek (helyzet, távolság) a vizsgálatokba történỏ hangsúlyozott beemelésével, a gazdaságon kívuili kérdéskörökben is a modellező, általánosító elméleti irányzat vezetö szerepét hozta. Ennek az irányzatnak az utolsó nagy, igazi újdonságokat hozó hulláma a nyolcvanas évek közepén tetözö diffúzió-kutatás volt, ami különösen értékes szemléleti többletként - elöször tette e térbeli, területi közelítéssel egyenrangúvá a regionális kutatásokban az idóbeliség szempontját. Itthon e témakörben, néhány korrekt elméleti tanulmányon túl, figyelemre méltó, szintetikus munka is születetett (Rechnitzer 1993). Nálunk még egyértelmüen kényelmes gyerekcipóben jár (a tematikus térképek gyors, számítógépi elkészítésének szakaszában, a modern kartográfia ,profi” eszközeitöl - I. Zentai L. 2003 - azonban még jócskán lemaradva) a földrajzi információs rendszerek technikáinak társadalomelemzési felhasználása, ami, most már érzékelhetően, egy újabb módszertani forradalmat alapoz meg (Ball 2002).

Tólünk Nyugatra sorra szuiletnek a kifejezetten a lokalizált, térbeli adatok elemzésére használható szoftverek, s ezek bázisán nagy ütemben hatol be a térszempontú elemzés a legkülönbözőbb problémakörökbe. Csak egyetlen példát említve: az Amerikai Nemzeti Igazságügyi Intézet (The National Institute of Justice) lokalizált bünügyi adatok feldolgozására dolgozta ki CrimeStat nevú programrendszerét, ami azonban egy generális térelemzö eszköz, kiválóan használható bármely más térbeli pontrendszer (cégek, intézmények) elemzésére is. A program az. Internetröl letölthetö - ugyanis állami pénzből készuilt, a polgároknak -, ajánlom minden hazai elemző figyelmébe (ha más nem, ennyi haszna legyen az olvasónak ebböl az elméleti írásból). E tendenciával sajátos ellentmondásban a geográfián, a területi elemzésen belül eluralkodott egy nem pusztán nem-kvantitatív, de kifejezetten anti-kvantitatív irányzat, ahogy azt A.S. Fotheringham és két szerzötársa az egyik legújabb módszertani monográfia első bekezdésében rezignáltan megjegyzi (Fotheringham et al 2000).

A hetvenes évektöl a behaviourista fordulat, a regionális politikai kihívások vagy (a kapcsolódó tudományterületek példájával élve) a kritikai vagy radikális geográfia (Timár 2001) újra a társadalmi és politikai determináltságra teszi a hangsúlyt. 
Nemes Nagy József : A regionális tudomány dualitása és paradigmái - hazai tükörben.

Tér és Társadalom 17. évf. 2003/1. 1-17. p.

Egyértelmủen ilyen karakterủ a kilencvenes évek regionális tudományi szemlélete az átalakuló kelet-közép-európai országokban is. E sajátos folyamatok, s a velük szinte egy időben felerősỏdő globalizálódás azonban egy közös momentum következtében újra kiemelten tereli rá a figyelmet a térbeliségre: az átalakulást minden szinten, a tradicionális vagy új reáltartalmak mentén, mértékében ugyan különböző, de alaptrendjében növekvö térbeli differenciálódás kíséri. A hatótényezők, okok keresésében ezért természetszerủen előtérbe kerül a fekvés, a térbeli kölcsönhatás, az „új geográfikum” momentuma. A regionális tudomány növekvő elismerésében, felértékelödésében nemcsak a regionalisták eredményeinek, hanem annak is fontos szerepe van, hogy a teret, a térbeliséget korábban lényegében ignoráló tradicionális társadalomtudományok a maguk új összefüggéseit, törvényeit keresve újra felfedezik a teret. Így megfordulóban van a korábbi egyoldalú viszony, amikor a területi kutatók a társadalomtudományok eredményeiből merítve dolgoztak, ma a tág társadalomtudomány is felhasználja a regionális tudományban kialakult elméleti és módszertani eszköztárat.

A társadalmi és gazdasági egyenlötlenségek kutatásában például a társadalmi és a térbeli faktorok kikerülhetetlenül megjelenő sajátos dualitása mindenekelőtt a „fej" (a humán erőforrások) és a „hely” (a fekvés, a környezet) egyaránt érdemi magyarázó erejü szerepére reflektál. A szociológia klasszikus módszerében, a véleménykutatásban a minták rétegzési szempontjai között előbb-utóbb fel kell bukkanjon a regionális szempont is (korábban legfeljebb a város-falu differenciáltság érvényesítéséig jutottak a mintavételes eljárások). Különösen jól jelzi ennek indokoltságát a választási-, illetve párt-preferenciákban nálunk is egyre markánsabban megjelenő regionális tagoltság.

De lépjünk át a modell második fogalmi körébe, a vizsgált folyamatok dimenziójába!

\section{Vizsgált folyamatok: reálfolyamat - irányítás}

A regionális kutatások szemléletét boncolgatva az elméleti keretek kettőssége mellé a vizsgált folyamatok esetében két jól elküilönülő társadalmi szegmens, $a$ társadalmi reálfolyamatok, illetve a társadalomirányítás illeszthetö.

A meghatározó (hazai) teruileti kutatók többsége inkább egyik vagy másik problémacsoportra koncentrál. A geográfus indíttatásúak jellemzően az előbbi, a jogászigazgatási alapképzettségűek utóbbi felé húznak. (Megelőzendő, hogy mások helyezzenek el a saját sémámban, magamat jellemzően a reálfolyamatokat elemzök közé sorolom - az irányítási kérdésekhez is leginkább e szálon keresztül kapcsolódtam.) A közgazdászok között találjuk a legtöbb „kettős lelkületü” kutatót. Nálunk a legjobb példa Bartke István munkássága (1. pl. Bartke 1989), de Enyedi György (inkább társadalompolitikai) vagy Rechnitzer János (inkább regionális politikai) összegzỏ munkái is duális jellegủek (Enyedi 1996; Rechnitzer 1998).

A modell e dimenziója kapcsán kérdéses lehet, hogy indokolt-e az irányítási momentumot a társadalomelméleti, a reálfolyamatokat pedig a térelméleti keretek mellé helyezni. A modell természetszerüen az egyes fogalmaknak csak a domináns kapcsolódásait jelezheti, s tulajdonképpen valamilyen fokon minden elem kapcso- 
latban van egymással, az irányítás társadalomelméleti oldalhoz kötése elsỏdlegesen és aktuálisan az irányítási folyamat hangsúlyos politikai tartalmából következik.

Azt, hogy az irányítás és a társadalomelméleti háttér összekapcsolódása nem pusztán deduktív elméleti séma, hanem valóban a jellemző kapcsolat, visszaigazolja az, hogy a területi irányítási kérdésekkel foglalkozó legjelesebb kutatók munkáiban (pl. Pálné Kovács 1999) kevés térelméleti kérdőjelet találunk (társadalomelméletieket és a gyakorlati politikára utalókat inkább). Az irányítási kérdéseknek a társadalomelmélethez, a társadalomtudományokhoz általában, ezen belül az igazgatástudományhoz, politológiához kötődése azonban az irányítási folyamatnak nem a térbeli momentumát tagadja, hanem csak azt érzékelteti, hogy itt a „,belsö” (szervezeti, funkcionális, hatalmi) térbeliség esik egyértelmüen nagyobb súllyal latba, szemben a ,külsö" (a földi térben lokalizált) térbeliséggel. Az irányítás és a reálfolyamatok viszonyából ide tartozik az is, hogy szinte nyomtalanul tünt el a hazai érdemi tudományos tematikából a területi irányítás direkt szembesítése a területi reálfolyamatokkal. A klasszikus minta - Vági (1982) - sajnos követök nélkül maradt, amire a rendszerváltozás aligha elégséges magyarázat (az irányítás és a reálfolyamatok kritikai szembesítésére most is lenne elég ok).

\section{Vizsgálati célok: elemzés - tervezés}

A modell következő szegmense a vizsgálati célok szempontját jelzi. Mivel a vizsgálati cél, illetve a vizsgált folyamat két, sok tekintetben egymást átfedő dimenzió, az elöző fejezetben leírtak további részletezésére, finomítására is mód van.

Ha a regionális kutatások sokszínü vizsgálati céljait összefoglaló kategóriákba soroljuk, szinte magától értetődỏen adódik az elméleti (alap) és a gyakorlati (alkalmazott) kutatási célok két nagy csoportja. E két általános tudomány-karakterológiai csoporthoz még konkrétabb tárgymegjelölés is köthető esetünkben: az elemzés, illetve a tervezés szempontja (orvostudományi analógiával élve a diagnózis és a terápia).

Az inkább az elemzésekhez vonzódó kutató számára ugyan csábító a saját szempontjának kiemelése, a regionális kutatások genezise, egész története és mai gyakorlata azonban a tervezési (mai divatosabb kifejezéssel: fejlesztési, programozási) célt a kezdetektől fogva legalábbis egyenrangúan kezelte az elemzésivel. A két szempontot tekintve több időszak s a mai állapotok is inkább a gyakorlatias, tervezési cél túlsúlyát jelzik. Tudományelméleti szempontból ezt tükrözik vissza azok az álláspontok (G. Benko [1999] is idéz ilyeneket), amelyek az egész regionális tudományt egészében az alkalmazott tudományok közé sorolják.

Bizonyos esetekben (nem egy mai PhD kutatási téma kapcsán is) felmerül az a kérdés, hogy a nagyon gyakorlatias, politikai tartalmakkal átszött tervezésifejlesztési célú munkák egyáltalában minősíthetők-e a tudományosság szemszögéból? E kételyekre kettős válasz adható. Egyrészt a tervezési folyamatban vannak olyan szakaszok, amikor ténylegesen a tudományos közelítésé az első hely (e ket- 
Nemes Nagy József : A regionális tudomány dualitása és paradigmái - hazai tükörben.

Tér és Társadalom 17. évf. 2003/1. 1-17. p.

TÉT XVII. évf. 2003 - 1

A regionális tudomány ...

tősséget jól példázza Kozma G. [2002] munkája, amely a helymarketing elméletét és gyakorlatba ültetésének útjait egyaránt bemutatja). Másrészt a tervezésnek, fejlesztésnek megvan, meg lehet a maga tudományos, tervezéselméleti tartalma (ez utóbbi terület kevés hazai müvelője közül kiemelkedik Faragó László szinte minden írása - az általam ismertek közül újabban 1. Faragó 2000). Ilyen tartalmak illetve kritériumok nélkül azonban még a legsikeresebb kistérség-fejlesztési terv vagy marketing-mix sem teljesíti a doktori értekezések tudományos követelményeit (nem is kell, hogy teljesítse, de nem is fogadható el értekezésként).

Érdemes végiggondolni a kutatási célok és a vizsgált folyamatok itt figyelembe vett két-két kategóriájának a lehetséges kombinációit is. Első közelítésben azt mondhatom: a regionális tudomány történetében a reálfolyamatok, illetve a társadalomirányítási kérdések kiemelt kutatása közel párhuzamosan fut az elemzö, illetve tervezỏ céllal, az elemzések a reálfolyamatokra koncentrálnak, a tervezési cél az irányítással kapcsolódik össze (Bartkénél, aki az irányítást kevésbé folyamatként, mint inkább feladatként fogja fel, a tervezés az irányítás része). Az összekapcsoltság azonban nem sémaszerü. Tekintsünk néhány példával is megerösítve ezekre a relációkra!

J. G. Williamson (1965), a területi egyenlötlenségek történeti és nemzetközi alakulását taglaló klasszikus munkája - ami a saját elemzői pályám elindításában a legfontosabb írás, s melynek újabb, átfogó tesztjét épp mostanság tervezzük kis csapatommal - tipikus példája a reálfolyamat - elemzés kombinációnak. A hazai szerzők közül ez a szemlélet domináns a magát regionalistának sohasem valló, de munkahelyi kötődése okán „korpa közé keveredett” Beluszky Pál kiemelkedő színvonalú településföldrajzi munkásságában (Beluszky 1999).

A regionális tudománynak is gyökerei közé tartozó (klasszikus) telephelyelméletekben, a területi optimumkeresésben a gazdasági reálfolyamatok a gazdaságon (vállalaton, cégen) belüli döntés momentumával kapcsolódnak össze (ebben az esetben tehát a reálfolyamat - tervezés kombináció esetével állunk szemben). Az Isardféle, születő regionális tudomány közelítése érthetöen leginkább ezzel volt rokon.

Az irányítás - elemzés kombináció a regionális kutatásokon jellemzően túlmutató, erős politikai tartalmú témakör. Kelet-Közép-Európa átmeneti országaiban azonban, ahol az új regionális politikai intézményrendszer kiépítése volt az elmúlt évtizedben napirenden, az elemzések alig jutottak túl a ,,(még) nem müködik” szindróma megállapításán, vagy megelégedtek azzal, hogy a formálódó intézményrendszer „EU-konform” (vagy mások szerint „nem EU-konform”). Ehhez a kombinációhoz kapcsolhatók ellenben épp az EU regionális politikai akciót, illetve ezek példáján a redisztribúciós momentumot, a bürokratikus jegyeket feszegető írások, vagy azok a kezdeti kísérletek, amelyek a fejlesztési folyamat monitoringját, a területi hatások kimutatását célozzák.

Ha nemcsak a vizsgálati célokat és folyamatokat kapcsoljuk össze, hanem a kiindulásként felvázolt duális elméleti hátteret is, akkor az eddig áttekintett fogalompárok a (hazai) regionális tudomány két, hangsúlyaiban, szemléletében jól 
Nemes Nagy József : A regionális tudomány dualitása és paradigmái - hazai tükörben.

Tér és Társadalom 17. évf. 2003/1. 1-17. p.

elkülönülő - bár természetesen mereven szét nem választható - kutatási vonalát jelölik meg:

a társadalomelmélet - tervezés - társadalomirányítás az elsỏ vonal,

a második láncot pedig a térelmélet - elemzés - reálfolyamatok vonal alkotja.

Elöbbiben - bár ott van -, jellemzöen a társadalmi tartalom mögé keruil a térbeli, területi szempont, utóbbira inkább az jellemző, hogy kiindulópontja a tér, a terület, s ez töltődik meg társadalmi tartalommal. Ha megpróbálunk kiszabadulni a tudományterületek értékelésében gyakorta megjelenỏ apologikus szemlélet csábítása alól (azaz a valóságos, s nem a kívánatos, elképzelt viszonyokat tekintjük mérvadónak), e két szemléleti vonal világos létét, s nem valamifajta tagolatlan komplexitást jelölhetünk meg a mai (s itt nem csak a hazai helyzetre gondolok) regionális tudomány jellegadó vonásaként - a már többszörösen hangsúlyozott, természetes összekapcsolódások ellenére.

Az első kutatási vonalhoz áll közelebb a magát a hazai regionális tudomány bázisintézményének tekintő MTA Regionális Kutatások Központja is. Legutóbbi - az Országos Területfejlesztési Tanács számára készített - kiadványában az intézet (MTA $R K K$ 2002) a következő területeken számol be kutatási eredményekról: EU-csatlakozás regionális politika, területi gazdaságpolitikai vizsgálatok, városhálózati vizsgálatok, a térségi struktúrák vizsgálatai, vidékfejlesztési kutatások, a magyar régiók és települések versenyképessége az európai gazdasági térben, a regionális intézményrendszer fejlesztése. (Az OTT vélhetöen nem hiányolta túl hevesen a térelméleti kutatásokat. Ezek vitele talán - az említett kiadványban felértékelöen „stratégiai partnerként” említett - egyetemek súlyponti feladata lehetne, ha a kutatómunkához a szükséges, de a tömegoktatás viszonyai között tovaillant idő biztosítható lenne.)

A tudományterület jövőjére tekintve az elméleti megalapozottság erősítésén túlmenỏen kívánatosnak épp e két kutatási-szemléleti vonal közelítése tủnik. Bizonyos tekintetben azonban ezt az elkülönültséget kevésbé tekintem komoly nehézségnek annál, mintha egyfajta kusza komplexitásból, összefonódásból kellene kibogozni az alapvetỏ szálakat (ez zavaros elemzók zavaros fejlesztési javaslatait eredményezi).

\section{A regionális tudomány paradigmái}

Áttérve a tanulmány második részére, a modell „szívére”, a következőkben azokat az átfogó sémákat, gondolati vonalakat próbálom felvázolni, amelyeket a regionális tudományban paradigma-értékünek tekintek.

A paradigma a tudományelmélet bevett fogalma, amelyet $E$. Babbie, átfogó társadalomtudományi módszertani múvében így határoz meg: „A paradigma olyan alapvetó séma vagy modell, amely szemléletünket valamely dologgal kapcsolatban szervezi és rendezi. Bár nem feltétlenül ad választ a fontos kérdésekre, de azt megmondja, hogy a választ hol keressük" (Babbie 1995, 78). Ugyanitt a szociológiai kutatásnak három alapvetô paradigmáját említi: az interakcionalista paradigma egyének közötti interakciókból álló folyamatként szemléli a társadalom életét, a strukturalista-funkcionalista paradigma a társadalmi élet szervezeti struktúrájára összpontosít, végül a konfliktusparadigma versengô egyének és csoportok harcaként szemléli az életet. 
Nemes Nagy József : A regionális tudomány dualitása és paradigmái - hazai tükörben.

Tér és Társadalom 17. évf. 2003/1. 1-17. p.

TÉT XVII. évf. 2003 m 1

A regionális tudomány...

11

A tudományok fö paradigmáinak megjelölése hosszú fejlődési időszak elmélyült elemzésére épülhet. A regionális tudomány egészét érintỏ ilyen munkák hiányában az alábbiak csak kísérletet jelentenek ezek megfogalmazására. Hangsúlyozom: a különböző paradigmák között (ha egy szemlélet valóban paradigma-értékü) nincsenek hamis és igaz paradigmák, csak különbözö közelítések, hangsúlyok sokfajta átfedéssel, ugyanannak a társadalmi folyamatnak más-más interpretációjával. Igaza van Enyedinek, amikor azt hozza fel példaként, hogy Budapest éppúgy értelmezhető nagyvárosként, mint városrégióként (Enyedi Gy. szóbeli közlése alapján).

A regionális tudomány első 25 évének hullámzó kutatási hangsúlyairól - benne olyan, mára szinte elfeledett nagy kutatási témákról, mint a területi input-output elemzés, de már kiemelten megjelenítve a helyi és regionális tervezési tematikát - tartott előadást Peter Nijkamp 1985-ben Budapesten (Nijkamp 1985). A korábban már említett Strassoldo a társadalmi térformákat és térkategóriákat briliánsan osztályozó tanulmányában a matematikai tértudományok (a tér) paradigmatikus fogalmaként a távolságot, a társadalomtudományok (a terület) központi koncepciójaként az érték, az ökológia (a környezet) paradigmájaként a kölcsönös függöség (interdependencia) fogalmát jelöli meg (Strassoldo 1990, 23).

Miként szemlél(het)i tehát a regionalista a maga vizsgálati tárgyát, a társadalmi tér jelenségeit és folyamatait?

\section{Térbeli társadalmi egyenlötlenségek}

A regionális tudomány paradigma-értékü építőkövei két alapvető csoportba sorolhatók. A regionális tudomány legsajátabb, a társadalomelméletet és a térelméletet összekapcsoló kérdésfeltevésének felel meg a tudományág alapvető, belsö paradigmája: a térbeli társadalmi egyenlötlenség. Ez különösebb kifejtést nem is érdemel - aligha vitatható, hogy minden regionális tudományi kutatás mögött az az alaphelyzet és kérdés húzódik meg, hogy miért (miként) tagolódik és müködik differenciáltan, egyenlötlenül a térben a társadalom, s miként változtathatók, alakíthatók ezek az egyenlötlenségek? Miközben az egyenlötlenség (nem-azonosság) az idöés térbeli létezéstôl elválaszthatatlan, a konkrét tagoltság, differenciáltság társadalmi következményei nem hagyják egyszerü „adottságként” értékelni, hanem újból és újból felvetik megváltoztatásának szükségességét is. Ez a paradigma a társadalmi fejlödés átfogó koncepcióihoz leginkább a centrum-periféria elméleteken keresztül kapcsolódik.

A külsö paradigmák csokra színesebb, s épp ennek szálakra bontása lehet az egyik kulcs a különböző regionális tudományi szemléletek kimutatásához. Külső (vagy háttér-) paradigmának nevezem azokat a gondolati, kutatási irányokat, amelyek meghatározott társadalmi tartalommal jelenítik meg a társadalmi tér legalapvetőbb jegyeit, kategóriát. Ezek a térelem és a térszerkezet, valamint a település és a régió fogalmaihoz kötödnek.

A különböző külső paradigmákból induló gondolkodásban a regionalisták térfelfogása, térszemlélete, a térbeliség súlyának, szerepének eltérö értelmezése is megjelenik. A többi társadalomtudomány jellemzően nem ezeket, hanem a társadalmi folyamatok történetileg változó kulcselemeit (funkcióit) állítja a középpontba. Az 
Nemes Nagy József : A regionális tudomány dualitása és paradigmái - hazai tükörben.

Tér és Társadalom 17. évf. 2003/1. 1-17. p.

átjárás a két közelítés között lehetséges, ha nem is könnyü. Vizsgáljuk meg kissé részletesebben ezt a négy paradigma-értékủ fogalmat.

\section{Térelem, térszerkezet}

Abban a regionális kutatói szemléletben, amely a különböző társadalmi szereplöket (egyének, gazdasági alanyok, társadalmi csoportok, intézmények) tekinti kiindulási pontjának - térelméleti szempontból, kimondva vagy kimondatlanul -, tulajdonképpen a térelem fogalma áll a középpontban.

E szemlélet kulcsfogalma a térelemek és attribútumaik egyenlötlensége a térben. Ha megleljük és jól jellemezzük, megértjük az adott folyamat meghatározó szereplöit, magatartásukat, eljuthatunk a vizsgált jelenségkör térbeli egyenlötlenségi rendszerének megértéséhez. Ennek alakítása, például az egyenlötlenség mértékének csökkentése is a szereplök (a térelemek) megváltoztatására (számuk vagy jellemzöik módosítására) épüilhet. Ha deduktív módon ered az ilyen kutatás a társadalmi folyamatok nyomába, akkor épp az érintett társadalmi szereplóket keresi. Ha közelítése induktív (ez a jellemzőbb), akkor a feltételezett társadalmi főszereplők viselkedése, viszonyai következményeként jellemzi a társadalmi mozgásokat, és az ezek alakította térbeli differenciáltságot. E szereplök keresése a legkülönbözőbb társadalmi folyamatokban kétségkívül nagyon eredményes szemléleti irány, s generális kiindulópont a legkülönbözőbb társadalmi szférák kutatásakor.

Példák sokasága hozható az ilyen közelítésekre. Csak az újabb idők fogalomtárából szemezgetve, ebbe a vonalba sorolható például: a jelentős tỏkével alapított vállalkozások léte vagy hiánya (a gazdasági értéktermelés térbeli differenciáltságának vizsgálatakor), a települési infrastruktúra vagy funkciókészlet (a jóléti tagoltság tényezőinek vizsgálatában), a politikai-hatalmi szereplők eloszlásának vizsgálata (a politikai térszerkezet vagy az esélyegyen]őtlenségek elemzésében). Mennyiségi jellemzésükkor e szereplök száma és nagysága, hatásuk árnyaltabb feltárására törekedve pedig beágyazottságuk, tradícióik, innovatív képességük egyenlötlenségeinek megjelölése fontos adalék a társadalomelemzésben.

Az már szemléleti és kutatás-módszertani szempontból más kiindulást és utat jelöl $\mathrm{ki}$, ha a vizsgálat túllép az egyes társadalmi szférák (ágazatok) jól megfogható karakteres építőkockáin, szereplöin, s azok kölcsönkapcsolatait firtatja. Az egyes társadalmi szférákon belüli egyenlötlenség vagy szegregáltság például viszonylag könnyen felmérhető, de a társadalom összetett térbeli tagoltságának értelmezéséhez már más kiindulási pontok szükségeltetnek (település, régió).

A térszerkezet-paradigma ugyancsak hozzáköthetö a tér legáltalánosabb fogalmaihoz: itt a rendezettség, a konfiguráció áll a középpontban. Azt a sajátosságot emeli ki, hogy a térelemek és jellemzőik másként hatnak eltérö térbeli elrendezettségük következtében, hatásuk összeadódhat, vagy csökkenthetik, netán kiolthatják egymás hatását. Természetesen a kapcsolat a két fogalom között kölcsönös: minden konfiguráció kialakulására magára is hat a térelemek száma és minősége is.

A térszerkezet-paradigma a belső (hatalmi, politikai, szervezeti) terekben a kapcsolatok és viszonyok menti egyenlötlenség, alá-fölérendeltség, függés mechanizmusaiban a szó eredeti jelentésének megfelelö, és nem csak analóg értelmü hierarchiákban jele- 
Nemes Nagy József : A regionális tudomány dualitása és paradigmái - hazai tükörben.

Tér és Társadalom 17. évf. 2003/1. 1-17. p.

nik meg. A globalizáció kérdéskörének regionális tudományi közelítése ugyancsak e paradigmához áll legkỏzelebb, hisz itt egy új térszerkezet kialakulásáról van szó, új föszereplökkel és új kapcsolatokkal, s kirívó térbeli egyenlötlenségekkel a homogenizálódás mögött. (Egyetértek Faragóval, aki azt mondja, hogy „A globalizáció felfogható egy hatalmas hálózatként" [Faragó 2002]).

A térszerkezet-szemléletben bukkan fel leghangsúlyosabban a szinte magával a térrel azonosítható, legalapvetöbb térkategória, a távolság (s kisebb hangsúllyal a másik rendezettségi paraméter, az irány), e szemléletben a külső földrajzi tér kutatásának központi kategóriảja a fekvés (1. Észak-Dél, Nyugat-Kelet dualizmus).

\section{Település, régió}

A térelem és térszerkezet fogalmától még határozottabban a társadaìmi tartalom irányába elmozdulva két olyan újabb paradigma-értékü fogalomra bukkanhatunk, amelyek lehetővé teszik, hogy az egyes, sajátos társadalmi szegmensek (ágazatok) köréből kilépve az összetettebb, inhomogén társadalmi rendszereket vizsgáljuk.

Ez a két fogalom a regionális tudományi gondolkodásban a település, illetve a régió. Elỏbbi a térelem, utóbbi pedig a térszerkezet fogalmához kötődik eröteljesebben, de a különbségek a két-két fogalompár között távolról sem elhanyagolhatóak. Míg a térelem és a térszerkezet általános érvényủ, mind a kủlsö (a földi térben egyértelmủen lokalizált) térben, mind a belső térben (a földi lokalizációtól függetlenül is térjellemzőket mutató rendszerekben) fellelhető - a regionális tudomány egésze szempontjából ezért átfogóbb - fogalmak, a település és a régió kifejezetten csak a külső térre értelmezhetö. Abban az alkalmazott jellegü közelítésben, amely a regionális tudományt mintegy a területi tervezés tudományos háttereként pozícionálja, már leginkább csak a település és a régió fogalom jön szóba a gondolkodảst elindító paradigmaként.
A különböző tudományterületek közötti kommunikációs zavarok mélyén gyakorta épp a „,belső”, illetve a „külső” térre koncentráló szemlélet jellegzetes eltéréseit lelhet- jük meg. Jó példa erre a politológia és a politikai földrajz viszonya (Murphy 1999). Nehezen birkózik a területi elemzés a természet és a társadalom (kultúra) együttes térbeli elemzésével is. Ez az oka annak, hogy nem a természetfơldrajz legátfogóbb térkategóriája, a táj vált paradigma-erejü fogalommá és szemléletté a társadalmi tér kutatásában. A nemzetközi tudományosságban határozottan érzékelhető törekvés a táj természeti és a társadalmi összetevőket egyenrangúan magában foglaló értelmezésére (Jones-Atkinson 1999) hazánkban ma még sokkal inkább elvi kívánalomként bukkan fel, mintsem a konkrét kutatásokban valóságosan érvényesített szempontként. Többek között ez az alaphelyzet teszi részben kényszerủ szükséggé azt, hogy a regionális tu- domány társadalomtudományi karakterét hangsúlyozzuk.

A paradigma erejủ négy fogalom viszonylatában az is figyelmet érdemel, hogy míg a térelem és a térszerkezet között az egymásra épülés a jellemző logikai lánc, a település és régió fogalomban e viszony mellé már oda tehetó a szembenállás is, hatókörük, valóságos társadalmi magyarázó erejük megkérdőjelezése mindkét irányban. Szerepe van ebben a településhálózati „szövet” különböző vidékeken nagyon eltérő sürüségének éppúgy, mint a település és a régió, mint két térségi szint érdekellentéteinek a hatalmi, politikai (finanszírozási) viszonylatokban. 
Mind a település-, mind a régió-paradigma magában foglalja a település-, illetve a régió-típusok rendszerét. (Az egyedi, sajátos település, illetve térség - általánosabban: „az egyedi hely” - a társadalomföldrajz jellegadó kategóriája.) Ez a szempont lényeges lökést ad a két fogalom valóságos tudományos használhatóságának, hisz az egyedi településeket, illetve térségeket egy rendszer részeként értelmezi. A településtípusok esetében bizonyos könnyebbséget (bár kockázatot is) jelent, hogy itt egyszerü méretjellemzök (pl. a településnagyság) is megjelennek osztályozási szempontként, a térségtípusok esetében azonban a karakter, a fejlettség sokdimenziós „,minőségi” kategóriáira épül az osztályozás.

A település paradigmaerejü szerepét nagyban emeli, hogy e kategóriához kapcsolható a területi tudományok talán legkiterjedtebb hatókörü elmélete az urbanizációs ciklusokról. Különleges szerepet kap a település a korábban már emlegetett globalizáció tanulmányozásában is. A „városverseny” koncepcióján keresztül ez az alapkategória kiválóan használható a lokális-globális viszonyrendszer külsö térbeli tanulmányozásában, s még arra is alkalmas, hogy a „verseny” fogalmával elkenje, a „városéval” pedig megfoghatatlanná tegye a globalizáció kíméletlenségét (London, Tokyo vagy New York városok ellen senki sem tüntet).

Semmifajta sajnálkozás nincs bennem, csak tényként említem: a település paradigmaereje korlátokat is állít a regionális tudomány expanziója elé. E fogalom önmagában is olyannyira erós és gazdag, sok szálon futó gondolkodásra és érdemi kutatásra ad lehetőséget, hogy egy másik, sok tekintetben generális szerepre vágyó tudomány-terület, a telepiiléstudomány (urbanisztika) önállósulásához is érveket ad.

Az urbanizáció-elméletekhez (vagy a gyakorlatiasabb növekedési pólus-koncepcióhoz) mérhetö - a gyakorlat által is visszaigazolt elörejelzési elemeket is tartalmazó - elméleti séma a térség, a régió fogalmához nem kötödik.

Leginkább talán a regionális egyenlötlenségek, már említett, Williamsonhipotézishez kapcsolódó fejlödéstörténete, vagy az ifjabb innováció- és diffúzióelméletek tekinthetők ilyennek - az urbanizáció elméletét meg sem közelítő ismertség és elismertség nélkül. Ez elméleti szempontból kétségkívül gyengíti a régiócentrikus gondolkodás erejét. Sokak számára ugyanakkor a regionális tudomány azonos a régiók tudományával. A régió kitüntetett szerepét (akár szükebb, akár tágabb, összetettebb értelemben használjuk is a fogalmat) objektíve alátámasztja az a tény, hogy a társadalmi térszerveződés a maga teljességében csak elszigetelt településekben vagy akár települések hálózatában nem értelmezhető (a gazdaság bizonyosan települések, hálózatok, áramlások kitöltötte térségekben szervezödik és él). A térségi keretekben gondolkodás a gazdaságfejlesztés esetén nem is kérdőjelezhető meg, a régiókat középpontba állító tudományos gondolkodás a legnagyobb csapást az „egypont-gazdaság” szemléletére méri (a térszemléletnek a gazdasági elméletekre gyakorolt hatásairól 1. Dusek 2002b).

A komplex régiók kutatásakor érdemes tudnunk, hogy mára, a rendszerelméletböl kinőve lényegében önálló tudományággá vált maga a komplexitás-elmélet is. Íme egy újabb megismerésre érdemes modern ismeretkör. Ismeröi a területi kutatói körböl egyaránt figyelmeztetnek a komplex rendszerek leegyszerủsítésének és formális ,elbonyolításának" kutatási veszélyeire (Manson 2001; Reitsma 2003). 
Nemes Nagy József : A regionális tudomány dualitása és paradigmái - hazai tükörben.

Tér és Társadalom 17. évf. 2003/1. 1-17. p.

A régió-koncepcióval kapcsolatos elméleti bizonytalanságokat a legújabb idökben bizonyos mértékig kiegyenlíti az, hogy a társadalomalakítás (erősen gazdasági töltetü) modern térdimenziója, a területfejlesztés emblematikusan kötődik a régiók fogalmához.

\section{Befejezésül: gyökerek, módszerek}

A regionális tudomány paradigmái (bár át-átszövik egymást) jól köthetök a gyökereket alkotó egyes tudományterületekhez.

A térelem-paradigma a vállalat (cég, telephely) fogalmában a regionális gazdaságtanban jut kulcsszerephez, de a területi dimenziót sem kifelejtő társadalmi egyenlötlenség-kutatásokban a szociológia is ebböl a szemléletböl (egyének, társadalmi csoportok) indít, az igazgatástudomány intézményközpontú szemlélete is szorosan kötődik ide.

A térszerkezet-vizsgálatok tág értelemben leginkább a komplex földrajzi szemléletben (1. Peter Haggett térbeli rendszerfejlödési stádiumait), szűkebben a különböző hálózatok (föként az infrastruktúra) vizsgálatait gyakorta végző közlekedéstudományban és információs rendszerek vizsgálatában bukkannak fel.

A települést leginkább a társadalomföldrajzi és az urbanisztikai gyökerek emelték vezetô paradigmaként a regionális tudományba, de a sokat emlegetett, szociálpszichológiai tartalmú identitás is karakteresen a települések szintjén fogható meg. A településeknek a ,puhább” közelítésekben játszott kiemelt szerepét jelzi, hogy a tágabb térségi keretekre is kiterjesztett olyan fogalmak, mint hely-marketing, hely-imázs is jellemzően a lokális terekben fogható meg, és hat leginkább (Jankó 2002).

A régió már kissé „ridegebb” kategória, jól argumentálható léte elsődlegesen a gazdaságra szúkül, de összekapcsoltsága a hatalommal (regere - uralkodik, politikatudomány, politikai földrajz,) és a tervezéssel is erősödik, s a regionalizmus kapcsán a „puha” társadalomtudományok identitás-fogalma, a kulturális, etnikai meghatározottság itt is felmerül.

A négy paradigmatikus fogalom magában foglal olyan, ugyancsak alapvető társadalmi kategóriákat, amelyek a konkrét vizsgálatok során tovább gazdagítják, sok esetben kiteljesítik az adott paradigma mentén induló gondolkodást és kutatást. Ilyen fogalom például az erôforrás és a kibocsátás, valamint a háloózat és az áramlás. Ezek példájaként érdemes arra utalni, hogy számtalan regionális elemzés tárgya és eszköze a tőke különböző formáinak (eröforrások) vizsgálata. A kibocsátás-szemléletư kutatások központi kategóriájaként pedig ugyancsak privilegizált kategóriája az elméleti és gyakorlati (regionális politikai) szemléletủ kutatásoknak az értéktermelés (jövedelem, GDP). A hálózat-kutatások és a térbeli mozgások (áramlás, terjedés) vizsgálatai a térszerkezet vagy általában a területi fejlódés kutatásának fontos eszközei, mind statikus, mind dinamikus közelítésben.

Már kissé távolabb vezet a paradigmáktól, de érdemes arról is szólni még, hogy mindegyikre jellemző az, hogy kutatásmódszertani szempontból egyaránt utat nyitnak a szárazabb, de egzaktabb mennyiségi közelítésnek és a mélyebb, puhább, inkább az egyedi jegyeket felmutatni képes kutatási módszertannak. Leginkább a térelem-szemlélet a kiindulópontja a térparaméterekkel operáló matematikai model- 
leknek. Sok matematikai modellben persze maguk a települések illetve régiók sem önmagukban vizsgált összetett rendszerek, hanem különbözö jellemzökkel bíró, de önmagukon belül ekkor homogénnek tekintett térelemek. A település vagy régióközpontú gondolkodásban azonban inkább a szintetizáló, a rendszerek komplexitását leírni képes módszertan a jellegadó. A mennyiségi közelítések inkább az általános összefüggések keresését, a „minőségre” összpontosító (eset)tanulmányok az egyediség erejének bemutatására alkalmasak. Elöbbiekben általában kevés hely jut a modellből kilógó „reziduumok” (az egyediség), utóbbiakban pedig az egyediségben közös összefüggések bemutatásának. Bár erre aztán igazán kevés a példa, természetesen a két út kombinációja a kívánatos.

\section{Irodalom}

Anselin, L.-Griffith, D.A. (1988) Do spatial effects really matter in the regression analysis? - Papers of the Regional Science Association. Vol. 65. 11-34. o.

Babbie, E. (1995) A társadalomtudományi kutatás gyakorlata. Balassi Kiadó, Budapest.

Ball, J. (2002) Towards a methodology for mapping 'regions for sustainability' using PPGIS. - Progress in Planning. Vol. 58. 81-140. o.

Bartke I. (1989) A társadalom és a guzzlaság terilleti szerkezetének alapvonásai. Akadémiai Kiadó, Budapest.

Beluszky P. (1999) Magyarország telepiiléshálózata. Dialóg Campus, Budapest-Pécs.

Benedek J. (2002) A földrajz térszemléletének hullámai. - Tér és Társadalom. 2. 21-39. o.

Benko G. (1999) A regionális tudomány. Dialóg Campus, Budapest-Pécs.

Berényi I. (2002) A szociálgeográfia társadalomtudományi kapcsolódásai. - Abonyiné Palotás J.-Becsei J.Kovács Cs. (szerk.) A magyar társadalomföldrajzi kutatás gondolatvilága. SZTE Gazdaság- és Társadalomföldrajzi Tanszék, Szeged, 37-54. o.

Dusek T. (2002a) A területi autokorreláció. Fiatal Regionalisták III. Konferenciája, Győr. (elöadás)

Dusek T. (2002b) A gazdasági elemzések térszemlélete. Geográfus Doktoranduszok VI. Országos Konferenciája. Budapest. (elöadás)

Enyedi Gy. (1996) Regionális folyamatok Magyarországon az átmenet idöszakábın. Hilscher Rezsö Szociálpolitikai Egyesület, Ember Település Régió sorozat, Budapest.

Enyedi Gy. (2002a) A regionális tudomíny, MTA RKK ATI jubileumi konferenciája, Kecskemét. (elöadás)

Enyedi Gy. (2002b) La geographie humaine et la science rágionale en Hongrie. - Géographie, Économie, Société. 4. 347-353. o.

Faragó L. (2000) A (terület)fejlesztés irányítási algoritmusa a programozás. - Horváth Gy.-Rechnitzer J. (szerk.) Magyarország teriuleti szerkezete és folyamatai az ezredfordulón. MTA RKK, Pécs. 527-541. o.

Faragó L. (2002) A plurális tér egy olvasata. Kézirat.

Fotheringham, A.S.-Brunson, C.-Charlton, M. (2000) Quantitative geography. Perpectives on Spatial Data Analysis. Sage Publications, London.

Horváth Gy. (2001) A regionális tudomány, mint kutatási és oktatási diszciplína. - Évkönyv 200I. PTE KTK Regionális Politika és Gazdaságtan DI, Pécs. 11-23. o.

Illés I. (1975) Regionális gazdaságtan. Tankönyvkiadó, Budapest.

Illés I. (2002) Területfejlesztés Magyarországon a XX. században. Budapest. (kézirat)

Isard, W. (1956) Location and space-econom. MIT Press, Cambridge.

Isard, W. (1999) Further thoughts on future directions for regional science: A response to Fujita`s remarks on the general theory of location and space-economy. - The Annals of Regional Science. Vol. 33. 383-388. o.

Jakobi Á. (2002) A virtuális világ terei. - Magyar Tudomány. 11. 1482-1491. o.

Jankó F. (2002) A hely szelleme, helyimage, helymarketing. - Tér és Társadalom. 4. 39-62. o.

Jones, G.R.-Atkinson, M.S. (1999) Making a mariage with the land: the future of the landscape. Landscape and Urban Planning. Vol. 45.61-92. o.

Kozma G. (2002) Terület- és településmarketing. Debreceni Egyetem Kossuth Egyetemi Kiadó, Debrecen. Lefebre, H. (1974) La production de l'espace. Antropos, Puris.

Malmberg, T. (1980) Human Territoriality. Methuen, The Hague. 
Nemes Nagy József : A regionális tudomány dualitása és paradigmái - hazai tükörben.

Tér és Társadalom 17. évf. 2003/1. 1-17. p.

Manson, S.M. (2001) Simplifying complexity: a review of complexity theory, - Geoforum. Vol. 32. 405-414. o.

Markusen, A. (2001) Two frontiers for regional science: Regional policy and interdisciplinary reach. Papers in Regional Science. Vol. 81. 279-290. o.

Mészáros R. (2000) A társadalomföldrajz gondolatvilága. JATE, Szeged.

MTA RKK (2002) A magyar területfejlesztési gyakorlat tudományos megalapozása. Pécs.

Murphy, A.B. (1999) "Living together separately". Thoughts on the relationship between political science an political geography. - Political Geography. Vol. 18. 887-894. o.

Nemes Nagy J. (1998) A tér a társadalomkutatásban. Hilscher Rezsö Szociálpolitikai Egyesület, Ember Település Régió sorozat, Budapest.

Nijkamp, P. (1985) 25 years of regional science: retrospect and prospect. RSA 25. Európai Konferenciája, Budapest. (elöadás, kézirat)

Pálné Kovács I. (1999) Regionális politika és közigazgatás. Dialóg Campus Kiadó, Budapest-Pécs.

Rechnitzer J. (1993) Szétszakadás vagy felzárkózás. A térszerkezetet alakító innovációk. MTA RKK, Györ.

Rechnitzer J. (1998) Terulleti stratégiák. Dialóg Campus Kiadó, Budapest-Pécs.

Reitsma, F. (2003) A response to simplifying complexity.- Geoforum. Vol 34. 13-16. o.

Strassoldo, R. (1990) The Social Construction and Sociological Analysis of Space. - Hamm, B.Jalowiecki, B. (eds.) The social nature of space. Polish Academy of Science, Commitee for Space Economy and Regional Planning, Panstwowe Wydawnictvo Naukove, Warszawa. 20-47. o.

Szabó P. (2002) A térszerkezet fogalma a hazai területi egyenlótlenségi vizsgálatokban. Fiatal Regionalisták III. Konferenciája, Györ. (elöadás)

Timár J. (2001) A modern társadalomföldrajz szemlélete és módszerei. - Regionális Tudontányi Tanulmányok. 6. 49-60. o.

Varga A. (2002) Térökonometria. - Statisztikai Szemle. 4. 354-370. o.

Vági G. (1982) Versengés a fejlesztési forrásokért. KJK, Budapest.

Williamson, J.G. (1965) Regional inequality and the process of national development: a description of the patterns. - Economic Development and Cultural Change. 4. 3-84. o.

Zentai L. (2003) Output orientált digitális kartográfía. Budapest. (MTA doktora értekezés, kézirat)

\section{DUALITY AND PARADIGM OF REGIONAL SCIENCE - IN THE HUNGARIAN MIRROR}

\section{JÓZSEF NEMES-NAGY}

The paper - based on a general deductive model and the evaluation of the recent Hungarian mainstreams in the regional research - investigates the theoretical structure and contexts of the regional science. The regional science as a social science integrates the basic concepts, theories and methods of different regional studies concerned with spatial processes. The basic theoretical framework of the regional science is the duality of the general social theories and the social space theory. The processes investigated in the regional studies have two main characteristic directions: the analysis of the real social processes or the research of the systems of the public administration. These processes closely connected with the aims and methods of the regional analysis and planning. The author points out four paradigm of the regional science: the elements of the social space and the spatial structures as two general paradigm of the discipline, and the paradigm of the settlements and regions, as a special paradigm of the "outer" (geographic) space. 